\title{
Comparison of Adsorption Models for Determining Potassium Behavior of Some Selected Soil Series
}

\author{
Nabeel Rizwan ${ }^{1}$ and Qudrat Ullah Khan ${ }^{1 *}$ \\ ${ }^{1}$ Department of Soil Science, Faculty of Agriculture, Gomal University, Dera Ismail Khan, Pakistan. \\ *Corresponding Author Email: qudrat_baloch@yahoo.com \\ Received 22 June 2020, Revised 01 December 2020, Accepted 04 December 2020
}

\begin{abstract}
Potassium (K) availability to plants varies with the adsorption characteristics of soil, to evaluate the adsorption capacity, five soil series of different characteristics were used. $\mathrm{K}$ adsorption isotherms were performed by equilibrating $2.5 \mathrm{~g}$ soil samples with 10 levels of $\mathrm{K}\left(30-300 \mathrm{mg} \mathrm{kg}^{-1}\right.$ ) as $\mathrm{KCl}$ in $0.01 \mathrm{CaCl}_{2}$ solutions and shaken for $24 \mathrm{~h}$ at $25^{\circ} \mathrm{C}$. The amount of $\mathrm{K}$ adsorbed ranged from 33.2 to $94.9 \%$ of added K. Freundlich model explained K adsorption behavior better than the other two equations. Higher coefficient of regression values $0.99,0.97$ and 0.96 were recorded in Sultanpur (Silt loam), Naivela (Fine sandy loam) and Bhutesar (Clay loam), respectively. The highest $1 / \mathrm{n}$ value $1.54 \mathrm{~kg} \mathrm{mg}^{-1}$ and $\mathrm{kf}$ value $31.47 \mathrm{mg} \mathrm{kg}^{-1}$ of Freundlich isotherm were observed in Sultanpur (silt loam) due to high $\mathrm{pH}$, high $\mathrm{OM}$ and high clay contents, lowest values of constants were observed in Wajan (loamy sand) with $1 / \mathrm{n}$ value $0.44 \mathrm{~kg} \mathrm{mg}^{-1}$ and kf value $0.28 \mathrm{mg}$ $\mathrm{kg}^{-1}$ might be due to high $\mathrm{EC}$, high $\mathrm{CaCO}_{3}$ and sand contents. The $\mathrm{K}$ adsorption of soil varied with physico - chemical characteristics of soil, especially clay content, alkaline $\mathrm{pH}$ and organic matter content.
\end{abstract}

Keywords: Potassium, Adsorption, Freundlich, Langmuir and Temkin

\section{Introduction}

The dynamics of soil potassium $(\mathrm{K})$ and its availability to plant is regulated by the chemical and physical processes and phenomenon's of adsorption and desorption [1]. The sorption and desorption of potassium depend on the distribution and retention of $\mathrm{K}$ by the soil minerals [2]. $\mathrm{K}$ deficiency in different soils of Pakistan is increasing at a rapid rate. It has been found that $35 \%$ in KPK, $28 \%$ in Punjab and 8\% in Sindh [3] had improper plant accessible potassium. Elimination of straw from the field and applying $\mathrm{K}$ fertilizer at a lower rate affect potassium depletion in soil [4].

The physical, chemical and biological processes also affect the availability of $\mathrm{K}$ [5].
Amongst the solution and solid phase, adsorption is the gathering of the chemical sort [6]. The movement and fortune of nutrients in the soil are affected due to adsorption. Adsorption of $\mathrm{K}$ in the soil is influenced by the kind and quantity of clay minerals [7]. In the soil system, the movement of soil potassium depends upon the dynamics equilibrium. Several types of factors such as the category of clay mineral, tillage techniques, cation exchange capacity (CEC), fertilizer application, soil moisture contents, soil $\mathrm{pH}$, organic matter (SOM) contents and $\mathrm{Al}(\mathrm{OH})_{3} \quad$ [8] influence the dynamics equilibrium. 
Adsorption reaction involves the attachment of solution ions onto the surface of the solid soil particles [9]. Specific adsorption refers to the structural bonding between the ions and the surface of the soil particles. In the reaction, the $\mathrm{K}$ may either adsorbed quickly or slowly by dispersing through the micropores within the intra-crystalline sites or distant surfaces [10]. Adsorption phenomenon may be non-specific, specific and complex involving the soil organic matter. The association between the concentration of $\mathrm{K}$ in the solution phase and extents of immovable $\mathrm{K}$ per unit soil weight has been studied through $\mathrm{K}$ - adsorption isotherm or numerous curves. The adsorption is satisfactorily described by employing adsorption models. According to [11] the Langmuir and Freundlich are the most widely used models. The Freundlich equation resembles to a model of adsorption due to the rise in the amount of adsorption where the affinity duration decreases exponentially. Freundlich isotherm communicates $\mathrm{K}$ adsorption magnificently [12] in a narrow range of $K$ concentrations. On those surfaces where only one layer of molecules can be adsorbed, the Langmuir isotherm is imperfect. With the presence of several types of $\mathrm{K}$ sorption sites in the soils, the Langmuir model is incompatible [13], each with the different selectivity of K.

The relationship between $\mathrm{K}$ adsorption capacity and other soil properties can be clarified through the experiment of $\mathrm{K}$ adsorbing potential of soil [14]. The association between the sorption isotherm ( $\mathrm{K}$ quantity adsorbed by the soil) and the capacity of soil solution $\mathrm{K}$ is accomplished by this resolution. This contribution aware and assume to increase crop yield and productivity through plant nutrients attachment, contest or create an association with the soil and aids to boost fertilizer [15]. In order to understand its insistent nature and capacity of soil to supply $\mathrm{K}$ to plant and exchangeable $\mathrm{K}$ can be evaluated by using the $\mathrm{K}$ sorption isotherm [16]. Additionally, it also pronounces the interchange of $\mathrm{K}$ from the soils by other ions, especially calcium [17]. The current study was aimed to evaluate the $\mathrm{K}$ adsorption potential of soils having different characteristics and apply different adsorption models which better fit the adsorption isotherm.

\section{Materials and Methods Soil Sampling and Experimental Sites}

A laboratory experiment was carried out at the Department of Soil Science, Faculty of Agriculture, Gomal University, Dera Ismail Khan, KPK, Pakistan (Fig. 1). For this purpose, five different soil series of Dera Ismail Khan, i.e., Sultanpur (silt loam), Bhutesar (clay loam), Saggu (silty clay loam), Naivela (fine sandy loam) and Wajan (loam sandy) were collected from the Farm sites at a depth of $0-30 \mathrm{~cm}$ (Table. 1). At least one composite soil sample made from 5 cores was collected randomly from each sampling area with the help of augur. All composite soil samples were air dried and ground to pass through a $2 \mathrm{~mm}$ sieve. Each sampling site was classified according to USDA-classification and marked with a GPS (Table. 1) for accurate soil location.
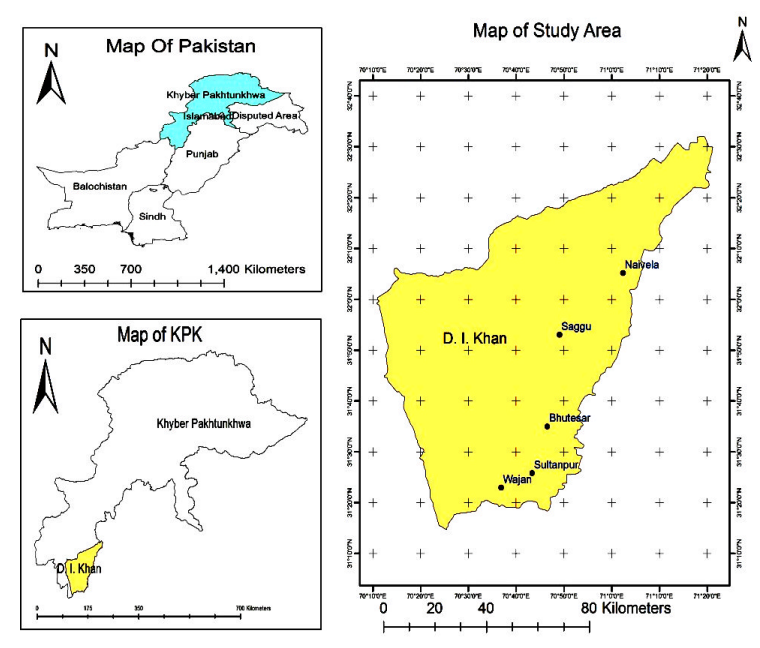

Figure 1. Location map of Dera Ismail Khan in Khyber Pakhtunkawa (Pakistan), and map of study area 
Table 1. Classification and location of Sultanpur, Bhutesar, Naivela, Saggu and Wajan soil series.

\begin{tabular}{|c|c|c|c|c|}
\hline Soil Series & Texture Class & Classification & Location & GPS Readings \\
\hline Sultanpur & Silt loam & Fluventic Haplocambids & D. G. Khan Road 48km southwest of D. I. Khan & $\begin{array}{l}\mathrm{N}(31.430227) \\
\mathrm{E}(70.722437)\end{array}$ \\
\hline Bhutesar & Clay loam & Typic Haplocambids & D. I. Khan- D.G. Khan road near Hazara village & $\begin{array}{l}\mathrm{N}(31.583788) \\
\mathrm{E}(70.775267)\end{array}$ \\
\hline Naivela & $\begin{array}{l}\text { Fine sandy } \\
\text { loam }\end{array}$ & Typic Torrifluvents & $\begin{array}{l}32 \mathrm{~km} \text { north of D.I. Khan along with the Kot Hafiz } \\
\text { Distributary }\end{array}$ & $\begin{array}{l}\mathrm{N}(32.086266) \\
\mathrm{E}(71.039136)\end{array}$ \\
\hline Saggu & Silty clay loam & Vertic Haplocambids & $11 \mathrm{~km}$ north-west of D. I. Khan on D.I. Khan-Tank road & $\begin{array}{l}\mathrm{N}(31.884382) \\
\mathrm{E}(70.818103)\end{array}$ \\
\hline Wajan & Loam sandy & Typic Torrifluvents & $\begin{array}{l}1 \mathrm{~km} \text { south-west of village Sarah Garah along the Ramak- } \\
\text { Kiri Shamozai road }\end{array}$ & $\begin{array}{l}\mathrm{N}(31.383002) \\
\mathrm{E}(70.614076)\end{array}$ \\
\hline
\end{tabular}

\section{Soil Analysis}

Prior to the adsorption study, soil physicochemical characteristics were determined (Table. 2). The soil properties determined included soil texture, Soil $\mathrm{pH}$ and electrical conductivity were determined by the procedure given by Ryan et al., [18]. While soil organic matter content [19], Calcium Carbonate [20] were determined titrimetrically. Soil nutrients, i.e., Extractable phosphorus [21] and Extractable K [22], were determined using the Spectrophotometer and Flame photometer, respectively.

Table 2. Physico-chemical properties of Sultanpur (Silt loam), Bhutesar (Clay loam), Naivela (Fine sandy loam), Saggu (Silty clay loam) and Wajan (Loam sandy) soil series.

\begin{tabular}{|c|c|c|c|c|c|}
\hline Location & Sultanpur & Bhutesar & Naivela & Saggu & Wajan \\
\hline $\mathrm{pH}$ & 8.58 & 8.19 & 7.31 & 7.35 & 7.01 \\
\hline $\mathrm{EC}\left(\mathrm{dsm}^{-1}\right)$ & 0.68 & 1.98 & 0.75 & 2.25 & 0.66 \\
\hline O.M \% & 0.75 & 0.61 & 0.39 & 0.33 & 0.41 \\
\hline $\mathrm{CaCO}_{3} \%$ & 7.6 & 8.3 & 12.21 & 15.5 & 13.4 \\
\hline $\mathrm{CEC}\left(\mathrm{cmol}_{\mathrm{c}} \mathrm{kg}^{-1}\right)$ & 17.51 & 11.32 & 12.32 & 9.01 & 9.21 \\
\hline $\begin{array}{l}\text { Available K } \\
\left(\mathrm{mgkg}^{-1}\right)\end{array}$ & 141 & 175 & 131 & 153 & 126 \\
\hline Clay $\%$ & 19 & 35 & 18 & 35 & 07 \\
\hline Silt $\%$ & 56 & 38 & 22 & 47 & 10 \\
\hline Sand $\%$ & 25 & 27 & 40 & 18 & 83 \\
\hline Texture class & $\begin{array}{c}\text { Silt } \\
\text { Loam }\end{array}$ & $\begin{array}{l}\text { Clay } \\
\text { Loam }\end{array}$ & $\begin{array}{l}\text { Fine } \\
\text { Sandy } \\
\text { loam }\end{array}$ & $\begin{array}{l}\text { Silty } \\
\text { clay } \\
\text { loam }\end{array}$ & $\begin{array}{l}\text { Loam } \\
\text { sandy }\end{array}$ \\
\hline
\end{tabular}

\section{Adsorption Study}

For the construction of potassium adsorption isotherm ten potassium concentrations as $\mathrm{KCl}(30,60,90,120,150$, $180,210,240,270$ and $300 \mathrm{mg} \mathrm{kg}^{-1}$ ) with 0.01 $\mathrm{M} \mathrm{CaCl}_{2}$ were made by adding $25 \mathrm{~mL}$ solution in $2.50 \mathrm{~g}$ of soil samples. Soil samples with $\mathrm{K}$ concentrations were shaken up to $24 \mathrm{~h}$ at 25 ${ }^{\circ} \mathrm{C}$ to enhance adsorption equilibrium.

The experimental data of $\mathrm{K}$ adsorption were subjected to adsorption equations given below:

\section{Langmuir adsorption equation}

$\mathrm{C} /(\mathrm{x} / \mathrm{m})=1 / k \mathrm{~b}+\mathrm{C} / \mathrm{b}$

Potassium concentration $\left(\mathrm{mg} \mathrm{L}^{-1}\right)$ in the equilibrium solution represented by $\mathrm{C}$ and potassium adsorbed per unit mass of soil $(\mathrm{mg}$ $\mathrm{Kg}^{-1}$ ) presented by $\mathrm{x} / \mathrm{m}$.

\section{Freundlich adsorption equation}

$\mathrm{x} / \mathrm{m}=\mathrm{a} C b$ By rearranging $\log (\mathrm{x} / \mathrm{m})=\log \mathrm{a}+$ $\mathrm{b} \log \mathrm{c}$

$\mathrm{x} / \mathrm{m}$ and $\mathrm{C}$ represent the mass of potassium adsorbed per unit mass of soil $\left(\mathrm{mg} \mathrm{kg}^{-1}\right)$ and the equilibrium solution potassium concentration $\left(\mathrm{mg} \mathrm{L}^{-1}\right)$, respectively.

$1 / \mathrm{n}$ and $\mathrm{kf}$ are constants obtained from the slope intercept, respectively.

\section{Temkin adsorption equation $\mathbf{x} / \mathbf{m}=\mathbf{a}+\mathbf{b} \ln \mathbf{C}$}

Where $\mathrm{C}$ and $\mathrm{x} / \mathrm{m}$ determine the equilibrium solution $\mathrm{K}$ concentration $\left(\mathrm{mg} \mathrm{L}^{-1}\right)$ and mass of 
potassium adsorbed per unit mass of soil ( $\mathrm{mg}$ $\mathrm{kg}^{-1}$ ), respectively.

Linear regression equations were applied to the adsorption data using the procedure given by Kunter et al., [23].

\section{Results and Discussion Adsorption Isotherm}

The curve formed in Sultanpur (silt loam) showed a linear trend from 30 to 150 $\mathrm{mg} \mathrm{kg}^{-1} \mathrm{~K}$, but at highest concentrations, 210 to $300 \mathrm{mg} \mathrm{kg}^{-1}$ showed a curvilinear trend. Maximum adsorption (69.04 \%) was recorded at $210 \mathrm{mg} \mathrm{kg}^{-1} \mathrm{~K}$. The $\mathrm{K}$ adsorption slightly decreased at higher K concentrations (Fig. 2). Maximum adsorption was observed in Sultanpur (silt loam) among other soil series due to maximum $\mathrm{pH}$ (8.58), high cation exchange capacity EC $17.51 \mathrm{cmol}_{\mathrm{c}} \mathrm{kg}^{-1}$ and high OM content $0.75 \%$ (Table. 2). As compared to soil mineral components the fast rate of $\mathrm{K}$ adsorption, which enhanced the adsorption of $\mathrm{K}$ was due to the existence of high organic matter. Presence of organic matter in soil release organic anions in the rhizosphere, which enhances the $\mathrm{K}$ adsorption capacity [24] due to the greater total negative surface charge of the soils.

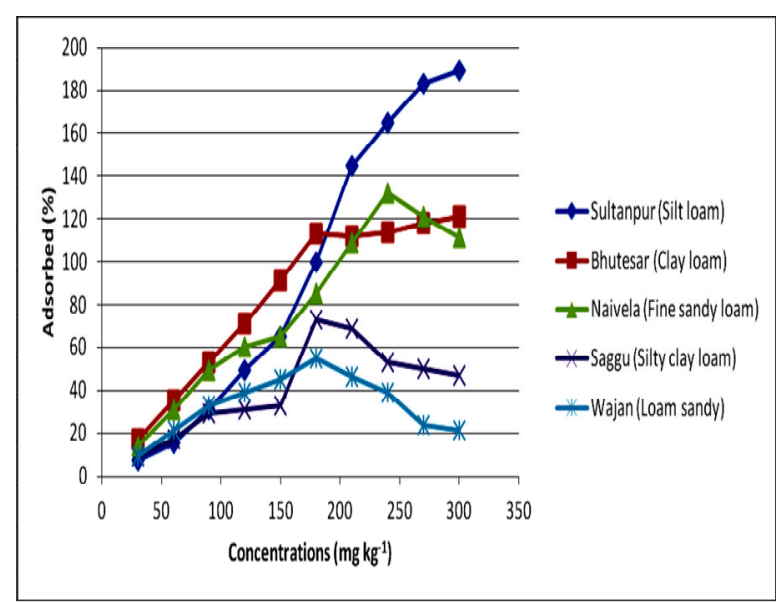

Figure 2. Different $\mathrm{K}$ concentration influenced $\mathrm{K}$ adsorption percentage on Silt loam, Clay loam, Fine sandy loam, Silty clay loam and Loam sandy of Dera Ismail Khan (Pakistan)
In Bhutesar (clay loam) soil series, the adsorption curve showed a linear trend initially, at higher potassium concentration curvilinear trend was observed. In Bhutesar (clay loam) soil series, maximum adsorption was recorded $(62.77 \%)$ at $180 \mathrm{~K} \mathrm{mg} \mathrm{kg}^{-1}$, which revealed that adsorption was comparable with Sultanpur (silt loam) among others (Fig. 2), influenced by the same physico-chemical properties with higher $\mathrm{pH}$ 8.19, Higher clay contents $35 \%$, OM $0.61 \%$ and lower $\mathrm{CaCO}_{3}$ contents $8.3 \%$ (Table. 2). At a higher concentration of $\mathrm{K}$ the clay loam soil texture showed an enhanced $\mathrm{K}$ adsorption rate initially but the rate reduced after some time [25]. Furthermore, it was found from the study that loam, silty clay loam and sandy clay loam textures showed a reduction in $\mathrm{K}$ adsorption in the start as the rate increase, it enhanced. In clay soils, maximum adsorption of $\mathrm{K}$ was observed as compared with the other textures.

Naivela (fine sandy loam) soil showed a nonlinear trend initially and remain linear at mid concentrations of $\mathrm{K}$. At maximum concentrations ranging from 240 to $300 \mathrm{mg}$ $\mathrm{kg}^{-1}$ the downward plateau in the curve was observed in the Naivela soils. Maximum adsorption was observed $51.90 \%$ at $210 \mathrm{mg}$ $\mathrm{kg}^{-1}$ (Fig. 2), this adsorption remains lower than Sultanpur (silt loam) and Bhutesar (clay loam) series. The texture class was fine sandy loam, pH 7.31 and low OM 0.39\% (Table 2). Through three different soils texture, the maximum $\mathrm{K}$ adsorption was due to factors including soil $\mathrm{pH}$, organic matter accumulation and clay mineral constituents [26]. The rate of $\mathrm{K}$ adsorption was increased by the change in $\mathrm{pH}$ value, while the capacity of $\mathrm{K}$ adsorption has been increased in the soils with $\mathrm{pH}$ range from 6 to 7.5.

The fourth soil series, namely Saggu (silty clay loam) showed a linear pattern initially, but a downward trend was observed from $180 \mathrm{mg} \mathrm{kg}^{-1}$. In applied concentration, the highest adsorption $40.55 \%$ was recorded 
at $180 \mathrm{mg} \mathrm{kg}^{-1}$ (Fig. 2). As compared to Sultanpur (silt loam), Bhutesar (clay loam) and Naivela (fine sandy loam), Saggu isotherm has lowest adsorption because of the lowest OM $0.33 \%$, high EC $2.25\left(\mathrm{dsm}^{-1}\right)$ and high $\mathrm{CaCO}_{3}$ contents $15.5 \%$ (Table. 2). Another characteristic, such as higher $\mathrm{CaCO}_{3}$ contents (lime) liable for the reduction in adsorption of $\mathrm{K}$ in soil. Due to the monovalent $\mathrm{K}$ ion, it can easily dislocate through the presence of lime containing divalent cations like calcium, which prefers calcium attachment on binding sites due to the greater cation exchange capacity of $\mathrm{Ca}^{2+}$. Thus $\mathrm{K}$ reduction in soil was observed due to the presence and accumulation of maximum $\mathrm{Ca}$ or Mg contents [27].

The $\mathrm{K}$ adsorption curve of Wajan (loam sandy) soil series showed a linear trend initially and bent from concentration $180 \mathrm{mg}$ $\mathrm{kg}^{-1}$ (Fig. 2). The highest adsorption rate was $36.66 \%$ at $90 \mathrm{mg} \mathrm{kg}^{-1}$. In Wajan (loam sandy), soil adsorption percentage was decreased gradually from $90 \mathrm{mg} \mathrm{kg}{ }^{-1}$. The properties of Wajan (loam sandy) soil series have neutral $\mathrm{pH}$, high $\mathrm{CaCO}_{3} 13.4 \%$ and sand contents $83 \%$ (Table. 2).

\section{Comparison of different sorption models}

The different model was used to explain the complex process of adsorption. In terms of sorption isotherm coefficient of determination was more favorable in the Freundlich equation as compared to Langmuir and Temkin equation (Fig. 3-5). Sultanpur series (silt loam) showed better in all three isotherm equations.

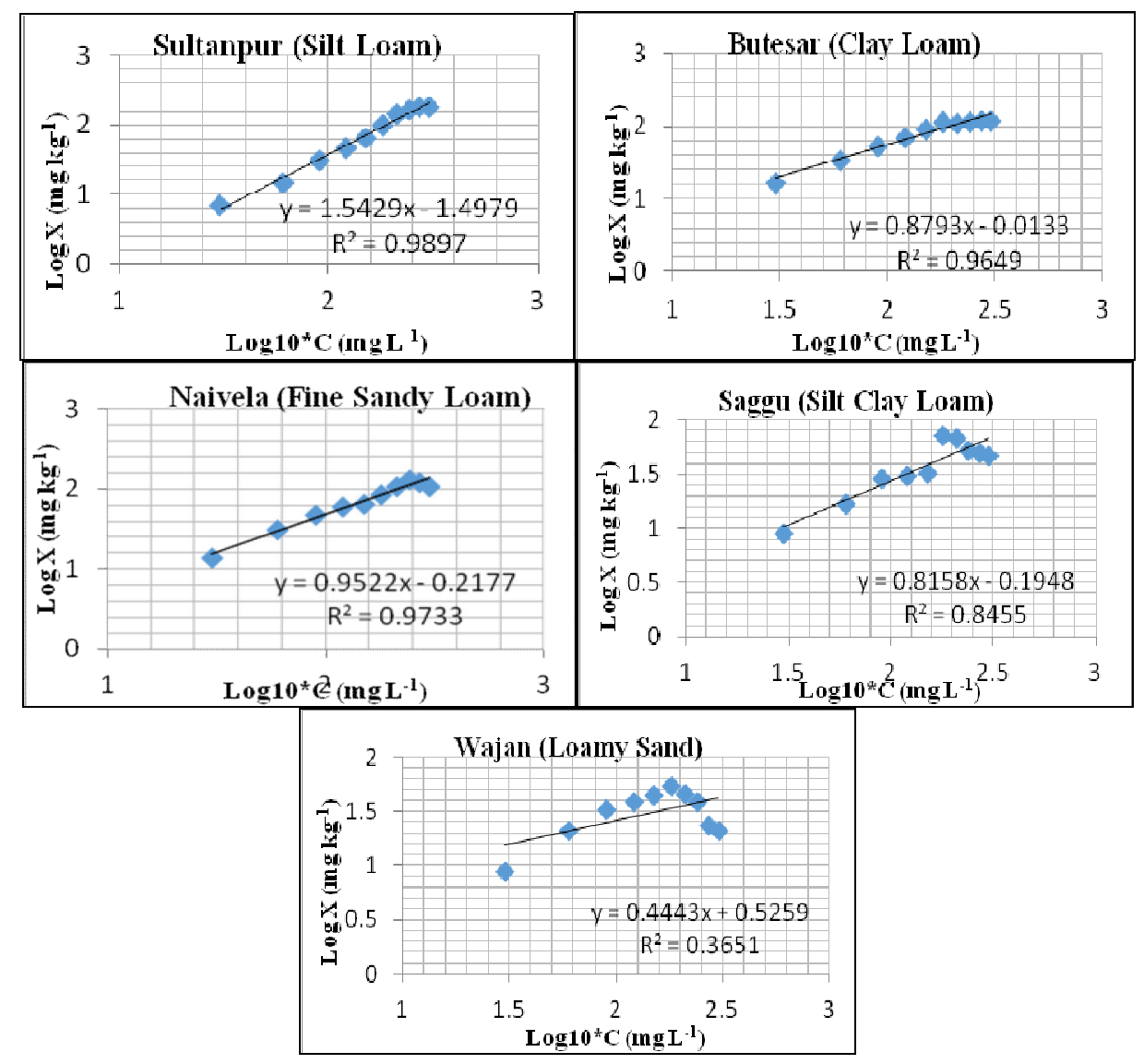

Figure 3. Freundlich adsorption isotherm of potassium adsorption for five soil series 

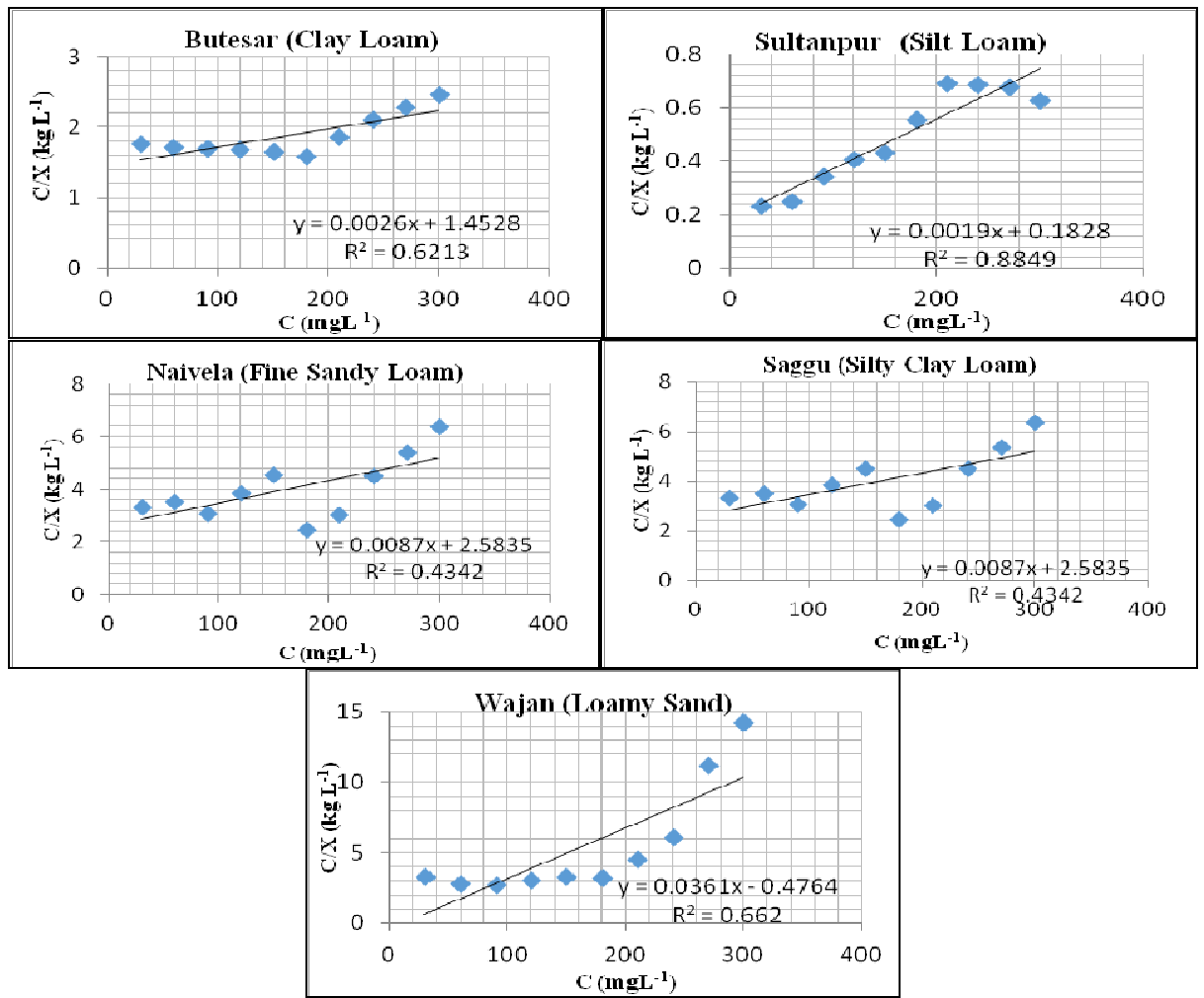

Figure 4. Langmuir adsorption isotherm of potassium adsorption for five soil series

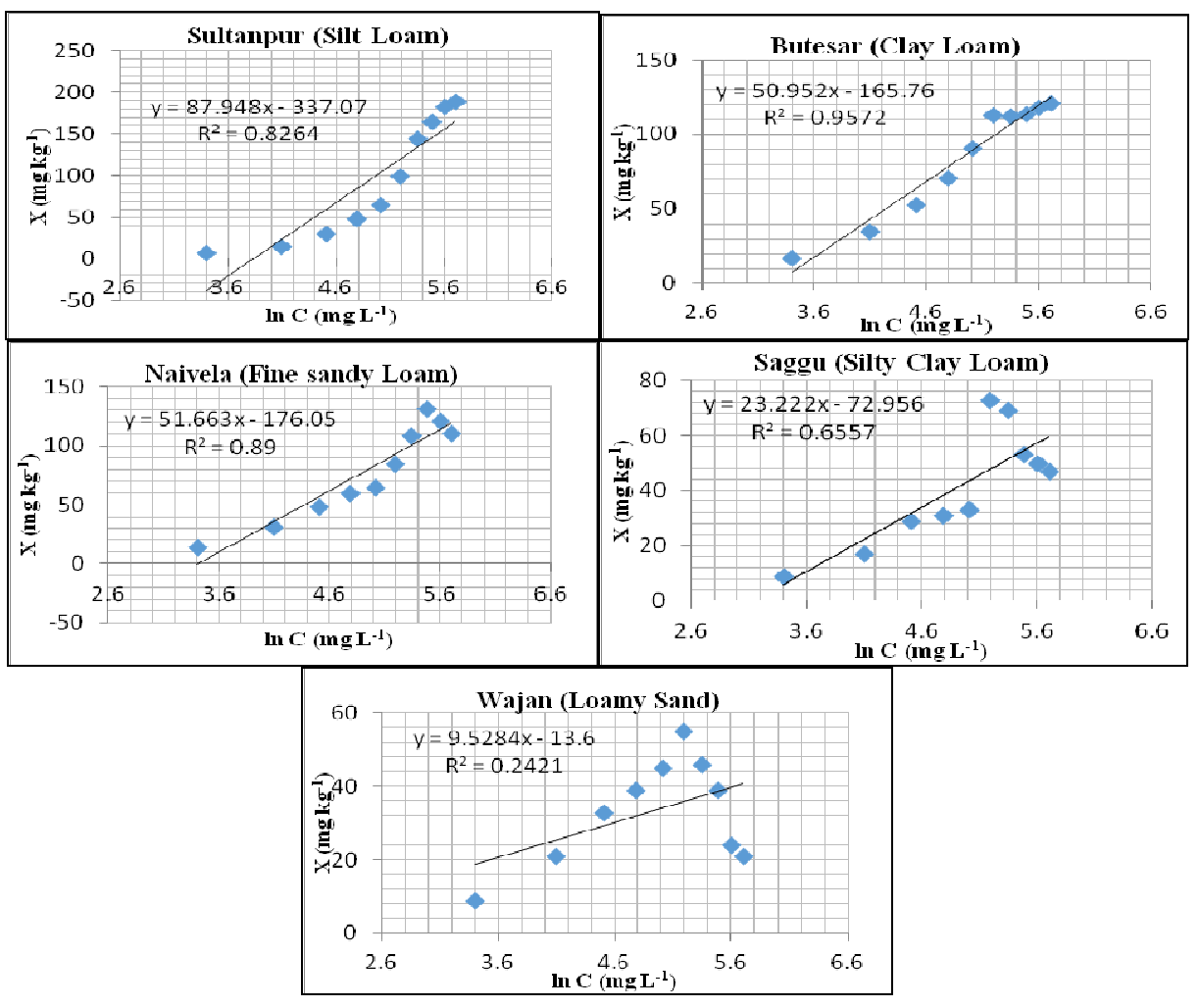

Figure 5. Temkin adsorption isotherm of potassium adsorption for five soil series 
In the Sultanpur series (silt loam) coefficient of determination of Freundlich equation was observed highest 0.99. This is due to the fact that Sultanpur series (silt loam) have high organic matter content $0.75 \%$, high clay contents and low $\mathrm{CaCO}_{3}$. Previous studies showed that for determining the heterogeneity, the Freundlich isotherm is considered as diver binding model and broadly valid for measuring and afford space for heterogeneity [28]. The Freundlich $\mathrm{R}^{2}$ value of Naivela (fine sandy loam) and Bhutesar (clay loam) series was 0.97 and 0.96, which was better than Saggu (silty clay loam) and Wajan (loam sandy) (Table. 3).

The Freundlich constant $1 / \mathrm{n}$ indicates the buffering capacity of the soil. In this study $1 / \mathrm{n}$ value showed from 0.44 to $1.54 \mathrm{~kg} \mathrm{mg}^{-1}$ [29]. Sultanpur (silt loam) has a greater $1 / \mathrm{n}$ value $1.54 \mathrm{~kg} \mathrm{mg}^{-1}$ due to the low sand contents $25 \%$. Similarly lowest $1 / \mathrm{n}$ value 0.44 $\mathrm{kg} \mathrm{mg}^{-1}$ was recorded in Wajan (loam sandy) soil due to high sand contents $83 \%$ (Table. 4). $1 / \mathrm{n}$ value indicated heterogeneity; smaller $1 / \mathrm{n}$ value reveals greater heterogeneity according to [30]. Our result was in accordance with researchers who reported that loam texture soil and sandy clay loam texture soil have a low $1 / \mathrm{n}$ value due to the presence of maximum sand proportions [25].

Freundlich $\mathrm{n}$ value determines the degree of non-linearity between the applied concentration and adsorption [31]. For a suitable sorption process [32], the value present in the middle of one and ten. If $\mathrm{n}$ value equal, less and greater than 1 it indicates that adsorption is a linear, chemical and physical process, respectively. In this study, $\mathrm{n}$ value of all soil series lies between 1 and 10 except $n$ value 0.65 was recorded in Sultanpur (silt loam) soil (Table. 4), for these sites sorption is favorable. They expect more than a single layer of adsorbed molecule.
The amount of $\mathrm{K}$ in the solid phase to the amount of $\mathrm{K}$ solution is the ratio of Freundlich constant $\mathrm{k}_{\mathrm{f}}$ [33]. The soil with more adsorption capacity have higher value of Freundlich $\mathrm{kf}$ constant and the soil having lower adsorption capacity have less value of Freundlich constant $\mathrm{k}_{\mathrm{f}}$ [33]. In this study Sultanpur (silt loam) has a high $\mathrm{k}_{\mathrm{f}}$ value 31.47 $\mathrm{mg} \mathrm{kg}^{-1}$ due to high $\mathrm{pH}, \mathrm{O} . \mathrm{M}, \mathrm{CEC}$, with low $\mathrm{CaCO}_{3}$ contents. The lowest $\mathrm{k}_{\mathrm{f}}$ value $0.28 \mathrm{mg}$ $\mathrm{kg}^{-1}$ was recorded in Wajan (loam sandy) due to high $\mathrm{CaCO}_{3}$ and sand contents (Table. 4). High adsorption capacity $\left(8.01 \mathrm{mg} \mathrm{kg}^{-1}\right)$ of clay loam soil might be due to minimum percentage of $\mathrm{CaCO}_{3}$, greater CEC (12.87 $\mathrm{cmol}_{\mathrm{c}} \mathrm{kg}^{-1}$ ), high $\mathrm{pH}$ (8.43) and greater fraction of clay substances as compared to other soils [13]. The maximum concentration of $\mathrm{K}$ is adsorbed through higher $\mathrm{pH}$ due to the formation of new sites and decreased the antagonism behavior between $\mathrm{K}^{+}$and $\mathrm{H}^{+}$for similar sites [34].

Langmuir coefficient of determination was lowest in all series except Sultanpur with $\mathrm{R}^{2}$ (0.88) (Table 3). In the Sultanpur soil the better fit of the data may be attributed to the percent organic matter and cation exchange capacity. In a similar study, a significant correlation was recorded between $\mathrm{K}$ adsorption and CEC and it was attributed to the availability of vacant sites for the adsorption of K [25]. The K adsorption data of the soils could not be suitable for the similar sites sorption with complete monolayer solute adsorption as assumes by Langmuir equation [35].

Temkin equation agrees with Freundlich coefficient of determination but has a lower $\mathrm{R}^{2}$ value. Temkin coefficient of determination was highest 0.96 in Bhutesar series (clay loam) as compared to other series (Table 3), our results were similar with Desta [31] that adsorption data of $\mathrm{K}$ for clay loam soil texture showed better fit in Temkin isotherm as compared to others. 
Table 3. Comparison of coefficients of determination $\mathbf{R}^{2}$ for the fit of the Freundlich, Langmuir, and Temkin equations to the sorption data of five soils.

\begin{tabular}{clc}
\hline \multicolumn{1}{c}{ Site } & \multicolumn{1}{c}{ Equations } & $\mathbf{R}^{2}$ \\
\hline Sultanpur & Freundlich $\mathrm{Y}=1.5429 \mathrm{x}-1.4979$ & $0.99^{* *}$ \\
& Langmuir $\mathrm{Y}=0.0019 \mathrm{x}+0.1828$ & $0.88^{* *}$ \\
& Temkin $\mathrm{Y}=87.948 \mathrm{x}-337.07$ & \\
Bhutesar & Freundlich $\mathrm{Y}=0.8793 \mathrm{x}-0.0133$ & $0.96^{* *}$ \\
& Langmuir $\mathrm{Y}=0.0026 \mathrm{x}+1.4528$ & $0.62^{* *}$ \\
& Temkin $\mathrm{Y}=50.952 \mathrm{x}-165.76$ & $0.96^{* *}$ \\
Naivela & Freundlich $\mathrm{Y}=0.9522 \mathrm{x}-0.2177$ & $0.97^{* *}$ \\
& Langmuir $\mathrm{Y}=0.0013 \mathrm{x}+1.8817$ & $0.21^{\text {Ns }}$ \\
& Temkin $\mathrm{Y}=51.663 \mathrm{x}-176.05$ & $0.89^{* *}$ \\
Saggu & Freundlich $\mathrm{Y}=0.8158 \mathrm{x}-0.1948$ & $0.85^{* *}$ \\
& Langmuir $\mathrm{Y}=0.0087 \mathrm{x}+2.5835$ & $0.43^{* *}$ \\
& Temkin $\mathrm{Y}=23.222 \mathrm{x}-72.956$ & $0.66^{*}$ \\
Wajan & Freundlich $\mathrm{Y}=0.4443 \mathrm{x}+0.5259$ & $0.37^{\mathrm{Ns}}$ \\
& Langmuir $\mathrm{Y}=0.0361 \mathrm{x}-0.4764$ & $0.66^{* *}$ \\
& Temkin $\mathrm{Y}=9.5284 \mathrm{x}-13.6$ & $0.24^{\text {Ns }}$ \\
\hline
\end{tabular}

** Significant at $\mathrm{P}=0.01 *$ Significant at $\mathrm{P}=0.05$

Ns = Non-significant

Table 4. Potassium adsorption parameters of the Freundlich equation.

\begin{tabular}{lccc}
\hline \multirow{2}{*}{ Sites } & \multicolumn{3}{c}{ Freundlich Isotherm } \\
\cline { 2 - 4 } & $\mathbf{1 / n}$ & $\boldsymbol{N}$ & $\boldsymbol{k}_{f}$ \\
\hline Sultanpur & 1.54 & 0.65 & 31.47 \\
Bhutesar & 0.88 & 1.14 & 1.03 \\
Naivela & 0.95 & 1.05 & 1.65 \\
Saggu & 0.82 & 1.23 & 1.57 \\
Wajan & 0.44 & 2.25 & 0.28 \\
\hline
\end{tabular}

\section{Conflict of Interest}

The authors declare that there is no conflict of interest.

\section{Conclusion}

The present investigation showed that soil properties influenced the $\mathrm{K}$ adsorption capacity of the soil. Increased soil EC exhibited maximum adsorption at lower concentrations due to the competition between $\mathrm{K}^{+}$and $\mathrm{Na}^{+}$ions on the clay surface. The soil series, i.e., Bhutesar and Saggu having high clay contents, which resulted in greater $\mathrm{K}$ adsorption at lower concentration due to engagement of clay contents with $\mathrm{Na}^{+}$ion and provide less vacant site for $\mathrm{K}$ adsorption. Amongst the different models applied, Freundlich model gave a better fit to all soil series than Langmuir and Temkin models. Freundlich constant $1 / \mathrm{n}$ value $1.54 \mathrm{~kg} \mathrm{mg}^{-1}$ and $\mathrm{kf}$ value $31.47 \mathrm{mg} \mathrm{kg}^{-1}$ was highest in Sultanpur (silt loam) due to high $\mathrm{pH}, \mathrm{CEC}$, $\mathrm{OM}$ and clay contents, lower $\mathrm{EC}$ and $\mathrm{CaCO}_{3}$ contents. The lowest value of constant was observed in Wajan (loam sandy) due to high EC, high $\mathrm{CaCO}_{3}$ and sand contents. We conclude that clay textured soil with high $\mathrm{pH}$ and high OM contents have positive affect on $\mathrm{K}$ adsorption capacity while factor like high $\mathrm{EC}$ and high $\mathrm{CaCO}_{3}$ contents have a negative effect on $\mathrm{K}$ adsorption capacity.

\section{References}

1. Y. Misskire, T. Mammmo, A. M. Taddesse and U. Yermiyahu, Comm. Soil Sci. Plant Anal., 50 (2019) 1132. https://doi.org/10.1080/00103624.2019.1 604732 .

2. A. Wakeel, H. U. Rehman and H. Megan, Int. J. Agric. Biol., 19 (2017) 381.

https://doi.org/10.17957/IJAB/15.0291

3. NFDC, NFDC publication No. 2/94, NFDC, Islamabad (1994).

4. E. M. A. Smaling, O. Oenema and L. O. Fresco., Nutrient disequilibria in agro ecosystems. Concept and case studies. CABI publishing University press, Cambridge, UK. 1 (1999) 157. https://research.wur.nl/en/publications/n utrient-disequilibria-in-agroecosystemsconcepts-and-case-studie.

5. International Plant Nutrition Institute. (IPNI), Better Crops. (1998) 82.

http://www.ipni.net/publication/bettercro ps.nsf/issue/BC-1998-3.

6. G. Sposito, Oxford University Press. (1989) 277.

https://doi.org/10.1002/ange.19901020446 
7. Y. Pal, M. T. F. Wong and K. J. Gilkes, Aust. J. Soil Res., 37 (1999) 695. https://doi.org/10.1071/SR98083.

8. R. P. S. Pannu, Y. Singh and B. Singh, $J$. Potassium Res. 19 (2003) 1.

9. J. M. Hannan, Potassium-magnesium antagonism in high magnesium vineyard soils. Masters thesis, Iowa State University (2011).

10. R. D. Harter and R. Naidu, Soil Sci. Soc. Am. J., 65 (2001) 597.

https://acsess.onlinelibrary.wiley.com/do i/abs/10.2136/sssaj2001.653597x

11. A. N. G. Boschetti, G. C. E. Quintero and Q. R. A. Benavidez, Rev. Bras. Ciênc. Solo, 22 (1998) 95. https://doi.org/10.1590/S010006831998000100013.

12. N. J. Barrow and J. W. Bowden, J. Colloid Interf. Sci., 119 (1987) 236.

https://doi.org/10.1016/00219797(87)90263-3

13. A. Hannan, A. M. Ranjha, M. W. Rahmatullah and A. Niaz, Pak. J. Agric. Sci., 44 (2007) 242. https://pakjas.com.pk/papers/320.pdf

14. M. A. Murashkina, R. J. Southard and G. S. Pettygrove, Soil Sci. Soc. Am. J., 71 (2007) 125.

https://doi.org/10.2136/sssaj2006.0060

15. A. H. Hunter., Laboratory and green house techniques for nutrient survey studies to determine the soil amendments required for optimum plant growth; Agro Services International: orange City, Florida (1980).

16. A. L. Yunda, G. Guzman, A. Ferrucho and L. R. Shelter, Colombian Mag. Chem., 26 (1997) 1.

http://dx.doi.org/10.15446/rev.colomb.q uim.

17. S. T. Bedrossian and B. Singh, Proc. of the 11th Cotton Conf. Brisbane, Convention and Exhibition Centre. $13^{\text {th }}$ $15^{\text {th }}$ August, (2002).
18. J. Ryan, G. Estefan, A. Rashid, Soil Plant analysis, Laboratory Manual. Int. Centre Agric. Res. Dry Areas. Aleppo, Syria (2001) 244.

https://www.aktion-

wuestenwald.de/english-version/.

19. D. W. Nelson and L. E. Sommer. Am. Soc. Agron., 9 (1982) 477.

20. G. E. Rayment and F. R. Higginson, Australian laboratory handbook of soil and water chemical methods. 56 (1992) 330. https://trove.nla.gov.au/work/34824443.

21. R. K. Lu, Soil agrochemical analysis. Agric. Sci. Techol., (1999) 560.

https://www.ifpri.org/search.

22. United State Department of Agriculture (USDA). Saline and Alkali Soils, Dignosis and inmprovement. Agric. Handbook No. 60, 160 (1954). https://www.ars.usda.gov/ARSUserFiles /20360500/hb60_pdf.

23. M. H. Kunter, C. J. Nechtsheim and J. Neter. Applied Linear Regression Models. 4th Ed. McGraw-Hill/Irwin New York, N.Y. (2004).

24. R. K. Xu, A. A. Zhen and J. Guo-Liang, Comm. Soil Sci. Plant Anal., 36 (2005) 1029.

https://doi.org/10.1081/CSS-200050424.

25. K. D. Auge, T. M. Assefa, H. W. Wassie and B. T. Asfaw, J. Soil Sci. Environ. Manag., 9 (2016) 1.

https://doi.org/10.5897/JSSEM2017.066 $\underline{6 .}$

26. A. Amouzadeh, A. Landi, S. Hojati, Majallah-i āb va Khāk., 30 (2017) 782. https://doi.org/10.22067/jsw.v30i3.39080.

27. H. Marschner, Marschner's mineral nutrition of higher plants. Academic Press (2011).

https://doi.org/10.1016/C2009-0-63043-9.

28. T. R. Gregory, C. L. Karns and K. D. Shimizu, Anal. Chim. Acta, 528 (2005) 107. https://doi.org/10.1016/j.aca.2004.07.048. 

29. O. Kenyanya, J. Muthengia and H.
Mbuvi., Int. J. Agric. Forestry, 3 (2013) 294.

doi:10.5923/j.ijaf.20130307.06.

30. A. O. Dada, A. P. Olalekan, A. M. 34. Olatunya and O. Dada, IOSR J. Appl. Chem., 3 (2012) 38.

31. M. B. Desta, J. Thermodyn., (2013) 1. https://doi.org/10.1155/2013/375830.

32. S. Goldberg, Equations and Models Describing Adsorption Processes in Soils. Soil Sci. Soc. Am., (SSSA) Book Series No. 8 (2005) 489. https://doi.org/10.2136/sssabookser8.c10
33. A. Shayan and B. G. Davey, Soil Sci. Am. J., 42 (1978) 878. https://doi.org/10.2136/sssaj1978.03615 995004200060007.

34. A. Loannu, A. Dimirku, J. Mitsios and M. Doula, Comm. Soil Sci. Plant Anal., 25 (1994) 1401.

https://doi.org/10.1080/00103629409369123

35. S. A. Bangroo, W. A. Mushtaq, A. Tahir, M. A. Malik, N. A. Kirmani, J. A. Sofi and R. Faisulur, Afr. J. Agric. Res., 7 (2012) 6502.

https://doi.org/10.5897/AJAR12.1751 